\title{
ARBUSCULAR MYCORRHIZAL FUNGI AND PHOSPHORUS DOSES ON COFFEE GROWTH UNDER A NON-STERILE SOIL ${ }^{1}$
}

\author{
SAMUEL DIAS MOREIRA ${ }^{2 *}$, ANDRÉ CABRAL FRANÇA² ${ }^{2}$ PAULO HENRIQUE GRAZZIOTTI ${ }^{3}$, FELIPE \\ DOUGLAS SOARES LEAL ${ }^{4}$, ENILSON DE BARROS SILVA ${ }^{2}$
}

\begin{abstract}
The use of mycorrhiza is a promising biotechnology that makes coffee cultivation sustainable in the use of fertilizers. In this sense, plant growth and phosphorus contents were assessed in coffee inoculated with Rhizophagus clarus, Claroideoglomus etunicatum and Dentiscutata heterogama in soil fertilized with 0 , $0.74,1.48$ and $2.96 \mathrm{~g} \mathrm{P}_{2} \mathrm{O}_{5} \mathrm{~kg}^{-1}$. The experimental design was a randomized block design in a $4 \times 4$ factorial scheme with four replications. The mycorrhizal seedlings were previously produced and later transplanted to pots, simulating the field planting. The assessments were performed 150 days after transplanting. All variables were influenced by inoculation, but the effects were dependent on $\mathrm{P}$ doses. $\mathrm{P}$ doses higher than $50 \%$ of the recommended dose $\left(0.74 \mathrm{~g} \mathrm{P}_{2} \mathrm{O}_{5} \mathrm{~kg}^{-1}\right)$ decreased the benefit of mycorrhiza. The fungi Rhizophagus clarus and Claroideoglomus etunicatum promoted a higher growth of coffee plants when compared to non-inoculated plants in non-sterilized soils and with a reduction in the applied P.
\end{abstract}

Keywords: Biotechnology. Coffea arábica L. Phosphate fertilization. Symbiosis.

\section{FUNGOS MICORRÍZICOS ARBUSCULARES E DOSES DE FÓSFORO NO CRESCIMENTO DO CAFEEIRO EM SOLO NÃO ESTERILIZADO}

RESUMO - O uso de micorriza é uma biotecnologia promissora a fim de tornar a cafeicultura sustentável na utilização de adubos. Nesse sentido, foi avaliado o crescimento e teores de fósforo em cafeeiro inoculado com Rhizophagus clarus, Claroideoglomus etunicatum e Dentiscutata heterogama em solo adubado com 0; 0,74; 1,48 e 2,96 $\mathrm{g} \mathrm{kg}^{-1}$ de $\mathrm{P}_{2} \mathrm{O}_{5}$. O experimento foi delineado em blocos e os tratamentos foram compostos pelo fatorial 4 x 4, com quatro repetições. As mudas micorrizadas foram previamente produzidas e posteriormente transplantadas para vasos, simulando o plantio no campo. As avaliações foram realizadas aos 150 dias após o transplantio. Todas as variáveis analisadas foram influenciadas pela inoculação, porém os efeitos foram dependentes das doses de $\mathrm{P}$. Doses de $\mathrm{P}$ maiores que $50 \%$ da dose recomendada $\left(0,74 \mathrm{~g} \mathrm{~kg}^{-1} \mathrm{de}_{2} \mathrm{P}_{2} \mathrm{O}_{5}\right)$ diminuem o benefício da micorriza. Os fungos Rhizophagus clarus e Claroideoglomus etunicatum promovem maior crescimento das plantas de café em relação às plantas não inoculadas, nos solos não esterilizados e com redução do $\mathrm{P}$ aplicado.

Palavras-chave: Biotecnologia. Coffea arábica L. Adubação fosfatada. Simbiose.

\footnotetext{
${ }^{*}$ Corresponding author

${ }^{1}$ Received for publication in $06 / 14 / 2017$; accepted in 08/01/2018.

Paper extracted from the master dissertation of the first author.

${ }^{2}$ Department of Agronomy, Universidade Federal dos Vales do Jequitinhonha e Mucuri, Diamantina, MG, Brazil; agronomia_samuel@yahoo.com.br - ORCID: 0000-0001-6385-5549, cabralfranca@yahoo.com.br - ORCID: 0000-0002-9009-3903, enilson.barros.silva@gmail.com-ORCID: 0000-0002-2088-9965.

${ }^{3}$ Department of Forest Engineering, Universidade Federal dos Vales do Jequitinhonha e Mucuri, Diamantina, MG, Brazil; grazziot@yahoo.com.br - ORCID: 0000-0002-9252-3065.

${ }^{4}$ Department of Plant Pathology, Universidade Federal de Lavras, Lavras, MG, Brazil; felipelealagro@hotmail.com - ORCID: 0000-00024327-9270.
} 


\section{INTRODUCTION}

The main form of coffee seedling production consists of sowing directly in polyethylene bags containing normally a low-fertility soil. The addition of nutrients to the substrate is essential for producing quality seedlings and hence a safe crop implantation (GUIMARÃES; REIS, 2010). However, these fertilizers have a high cost to seedling producers (LEMOS et al., 2015) and can change the costs of seedling production.

Fertilizers are a source of environmental pollution. A study of the surface water quality in the upper Acaraú River basin (Ceará) found a diffuse pollution generated by agricultural activities, diagnosed through the high concentrations of nitrate, sulfate, and phosphate in the waters (ANDRADE et al., 2007). The sustainability of agricultural systems is desirable, as well as is a high productivity and profitability (SANTOS et al., 2013). In this context, rationalization and alternatives more efficient in the use of fertilizers are associated with the economic security and agricultural sustainability.

Mycorrhiza as biotechnology in agriculture is considered one of the greatest pro-sustainability gains of the activity. Arbuscular mycorrhizal fungi (AMF) are obligatory biotrophic organisms that establish mutual associations with roots of most plants (JEFFRIES; BAREA, 2012) and are found naturally in coffee plantations (POSADA et al., 2018). However, some authors indicate the enrichment of the rhizosphere of coffee plants with selected AMF in order to take advantage of the benefits of symbiosis (FRANÇA et al., 2014).

The most important benefit of mycorrhizal association is a higher phosphorus $(\mathrm{P})$ absorption in low supply situations. In addition, $\mathrm{P}$ is the edaphic factor that most controls the percentage of colonization and the effects of symbiosis on plants. Depending on the amount of $\mathrm{P}$ available, the symbiosis may be of a mutualistic, neutralistic, or parasitic nature (SMITH et al., 2010).

Most of the studies on AMF inoculation and $\mathrm{P}$ doses were carried out on sterilized substrates in coffee seedlings, for example (ANDRADE; SILVEIRA; MAZZAFERA et al., 2010). However, substrate sterilization processes alter soil ecology (BERNS et al., 2008), thus influencing the effects of mycorrhizal association. In order to assess the efficiency of AMF inoculation in a coffee production system, it is necessary to use a substrate without sterilization, simulating field environmental conditions.

Therefore, plant growth and $\mathrm{P}$ contents were assessed in coffee plants previously inoculated with Rhizophagus clarus, Claroideoglomus etunicatum and Dentiscutata heterogama, cultivated on a nonsterilized soil and fertilized with increasing $\mathrm{P}$ doses.

\section{MATERIAL AND METHODS}

The experiment was designed in four blocks and arranged in a $4 \times 4$ factorial scheme and four replications. Seedlings of the cultivar Catuai Vermelho IAC 99 were inoculated with Rhizophagus clarus (RJN102A), Claroideoglomus etunicatum (RJN101A), and Dentiscutata heterogama (PNB102A) and non-inoculated (control) and transplanted to soils fertilized with $0.00,0.74,1.48$ and $2.96 \mathrm{~g} \mathrm{P}_{2} \mathrm{O}_{5} \mathrm{~kg}^{-1}$. The experiment was conducted in a greenhouse with one plant per pot $\left(20 \mathrm{dm}^{3}\right)$ constituting each experimental unit. The doses of $\mathrm{P}_{2} \mathrm{O}_{5}$ were obtained by applying simple superphosphate equivalent to $0,50,100$ and $200 \%$ of the fertilization recommended by Guimarães et al. (1999).

For seedling production, a sample of Oxisol (Latossolo Vermelho amarelo distrófico, Brazilian Soil Classification System) (Table 1) was sieved in a $4 \mathrm{~mm}$ sieve aperture, had its acidity corrected, and was fertilized according to a conventional recommendation (GUIMARÃES et al., 1999), except for $\mathrm{P}$. The fertilization with $\mathrm{P}$ consisted of $0.46 \mathrm{~g}$ $\mathrm{P}_{2} \mathrm{O}_{5} \mathrm{~kg}^{-1}$. The number of native AMF spores was assessed by the wet sieving technique, followed by centrifugation in water for three minutes at $3000 \mathrm{rpm}$ and in 50\% sucrose for two minutes at $2000 \mathrm{rpm}$ (GERDEMANN; NICHOLSON, 1963), and counted using a stereoscopic microscope. The number of native AMF spores was 15 spores per gram of soil.

Table 1. Characteristics of the Oxisol used for coffee cultivation in this study, as measured before fertilization and acidity correction

\begin{tabular}{|c|c|c|c|c|c|c|c|c|c|}
\hline $\mathrm{pH}\left(\mathrm{H}_{2} \mathrm{O}\right)$ & $\mathrm{P}$ & $\mathrm{K}$ & $\mathrm{Ca}^{2^{+}}$ & $\mathrm{Mg}^{2^{+}}$ & $\mathrm{Al}^{3^{+}}$ & $\mathrm{H}+\mathrm{Al}$ & $\mathrm{T}$ & $\mathrm{t}$ & O.M. \\
\hline \multirow[b]{2}{*}{4.9} & \multicolumn{2}{|c|}{$\ldots \mathrm{mg} \mathrm{dm}^{-3} \ldots$} & & .. $\mathrm{cmo}$ & & & & & \multirow{2}{*}{$\begin{array}{c}\text { dag kg-1 } \\
1.9 \\
\end{array}$} \\
\hline & 1.3 & 8.0 & 0.1 & 0.1 & 0.3 & 46 & 4.9 & 0.6 & \\
\hline P-rem & $\overline{Z n}$ & $\mathrm{Fe}$ & $\mathrm{Mn}$ & $\mathrm{Cu}$ & B & & Sand & Silt & Clay \\
\hline $\mathrm{mg} \mathrm{L}^{-1}$ & 21 & $\ldots \mathrm{n}$ & & & & & $\ldots \ldots$ & & \\
\hline 7.1 & 0.2 & 30.5 & 0.7 & 0.1 & 0.1 & & 38 & 8 & 56 \\
\hline
\end{tabular}

$\mathrm{pH}$ in water - soil-water ratio of 1:2.5; $\mathrm{P}, \mathrm{K}, \mathrm{Cu}, \mathrm{Fe}, \mathrm{Mn}$ and $\mathrm{Zn}-$ Mehlich-1 extractor; $\mathrm{Ca}, \mathrm{Mg}$ and $\mathrm{Al}-1 \mathrm{~mol} \mathrm{~L}^{-1} \mathrm{KCl}$ extractor; $\mathrm{H}+\mathrm{Al}-0.5 \mathrm{~mol} \mathrm{~L}^{-1}$ calcium acetate extractor; $\mathrm{OM}$ - organic matter: method of oxidation of carbon by potassium dichromate in an acid medium multiplied by 1.724; SB - sum of bases; $\mathrm{t}$ - effective cation exchange capacity; $\mathrm{T}$ - cation exchange capacity at $\mathrm{pH} 7.0 ; \mathrm{m}$ - aluminum saturation; $\mathrm{V}$ - base saturation. 
Coffee seeds were germinated in washed sand and transplanted when they reached the "matchstick" stage, before releasing the hypocotyledonary leaf. Inoculated seedlings were obtained by adding inoculant of the respective fungi composed of sand, expanded clay, and root fragments sufficient to provide 100 spores per seedling when transplanting them to polyethylene bags containing $1.6 \mathrm{dm}^{3}$ of soil. The inoculant was obtained from the Coleção Internacional de Cultura de Glomeromycota (CICG www.furb.br/cicg). Previously, spores were counted using a stereoscopic microscope. Seedlings from control did not receive any type of inoculum. Seedlings were developed under these conditions for 150 days when presented between 4 and 5 pairs of leaves. After this period, these seedlings were assessed for height and leaf area as described by Antunes et al. (2008). Sixty-four seedlings were chosen for transplantation to pots so that the sample was homogeneous.

Simulating the transplanting to the field, seedlings were transplanted to pots of $20 \mathrm{dm}^{3}$ of the soil mentioned above (Table 1), corrected for acidity and conventionally fertilized, except for P. For P, fertilization followed the established treatments. Subsequently, those plants were grown in a greenhouse for 150 days.

At the end of this period, soil samples were collected from all the experimental units to determine the chemical analysis of $\mathrm{P}$ by the Mehlich1 extractor and AMF spore density by the wet sieving technique (GERDEMANN; NICHOLSON, 1963). The plants were assessed again for height and leaf area, cut close to the soil surface, and their roots were washed with running water until total soil removal. A sample of approximately $2 \mathrm{~g}$ of thin roots was cut into 1 to $2 \mathrm{~cm}$ fragments and stored in a formaldehyde: acetic acid: $96 \%$ ethanol solution for further assessment of the percentage of root length colonized by the intersection method between gridlines (GIOVANNETTI; MOSSE, 1980) after depigmentation and coloring of roots, as proposed by Phillips and Hayman (1970). The remaining roots were dried in an air circulation oven at $65{ }^{\circ} \mathrm{C}$ for 72 hours. All leaves were ground in a Willey mill and submitted to nitro-perchloric digestion for further determination of P contents (MALAVOLTA, 2006).

The increase in height and leaf area was determined by subtracting the values obtained after growing for 150 days in the greenhouse from the values observed when transplanting the seedlings to the pots.

The data were submitted to analysis of variance using the F-test $(p \leq 0.05)$ and the significant interaction was sliced through the regression analysis.

\section{RESULTS AND DISCUSSION}

All the analyzed variables were influenced by the inoculation, but the effects were dependent on $\mathrm{P}$ doses.

Coffee plants inoculated with $R$. clarus and C. etunicatum presented higher heights when compared to non-inoculated plants (control), mainly at doses lower than $0.74 \mathrm{~g} \mathrm{P}_{2} \mathrm{O}_{5} \mathrm{~kg}^{-1}$ (Figure 1). In relation to the control, the highest increment in plant height promoted by AMF inoculation was observed when they were grown in soil without $\mathrm{P}$ addition. The increment in height of non-inoculated plants was $19.6 \mathrm{~cm}$ and that of plants inoculated with $D$. heterogama, $R$. clarus and $C$. etunicatum was $20 \%$ $(24.5 \mathrm{~cm}), 26 \%(26.5 \mathrm{~cm})$, and $28 \%(27.3 \mathrm{~cm})$ higher, respectively. The increase in increment of plants inoculated with $R$. clarus, $C$. etunicatum and non-inoculated presented a quadratic behavior, which decreased after a maximum increase. A reduction of this effect was observed in the higher $\mathrm{P}$ doses. For these cases, the maximum increment was observed in plants inoculated with $R$. clarus grown in soil with $1.40 \mathrm{~g} \mathrm{P}_{2} \mathrm{O}_{5} \mathrm{~kg}^{-1}$. With the $\mathrm{P}_{2} \mathrm{O}_{5}$ addition, non-inoculated plants increased their height until reaching a maximum point at the dose of $1.71 \mathrm{~g} \mathrm{P}_{2} \mathrm{O}_{5}$ $\mathrm{kg}^{-1}$. For plants inoculated with $D$. heterogama, the increase in $\mathrm{P}_{2} \mathrm{O}_{5}$ doses increased exponentially the increase in plant height, in which the highest increase was observed in the highest $\mathrm{P}_{2} \mathrm{O}_{5}$ dose. 


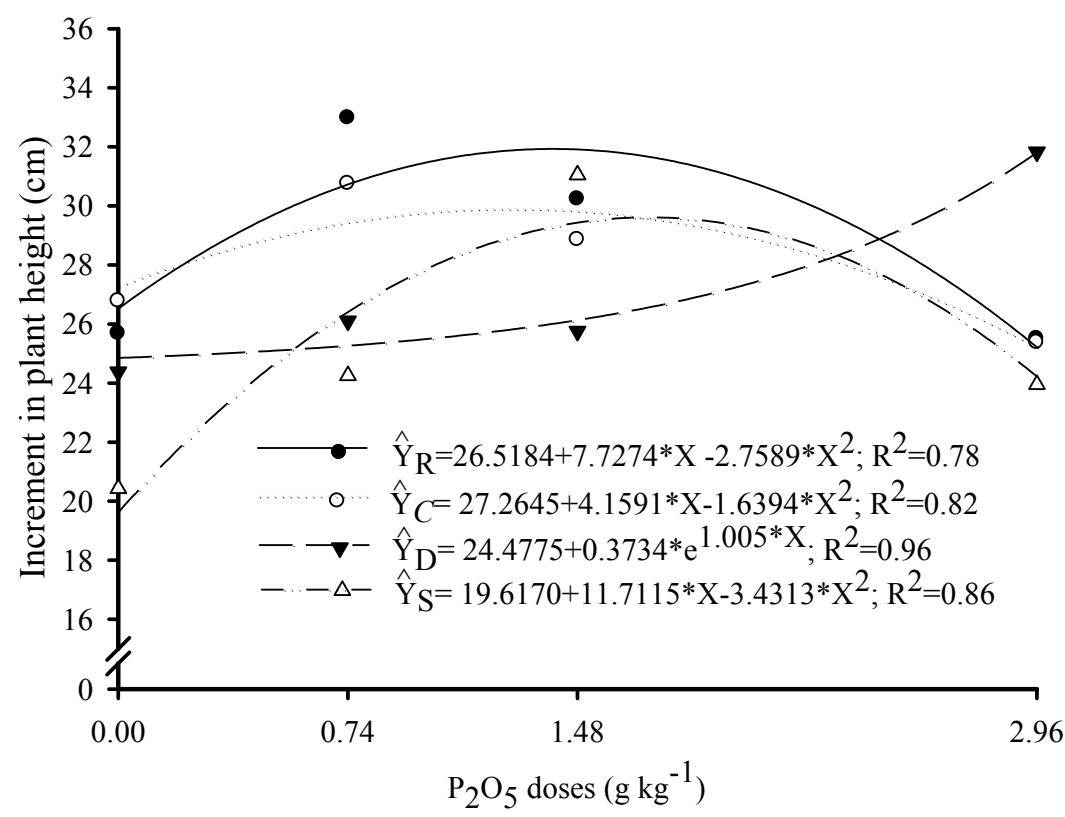

Figure 1. Increment in height of coffee (Coffea arabica) inoculated with Rhizophagus clarus ( $\mathrm{Y}_{\mathrm{R}}$ ), Claroideoglomus etunicatum $\left(\mathrm{Y}_{\mathrm{C}}\right)$ and Dentiscutata heterogama $\left(\mathrm{Y}_{\mathrm{D}}\right)$, and non-inoculated $\left(\mathrm{Y}_{\mathrm{S}}\right)$ and grown in soil with increasing $\mathrm{P}_{2} \mathrm{O}_{5}$ doses.

The inoculation with $R$. clarus increased the leaf area of plants over the 150 days of growth in soil fertilized with up to $1.11 \mathrm{~g} \mathrm{P}_{2} \mathrm{O}_{5} \mathrm{~kg}^{-1}$. In plants inoculated with $C$. etunicatum, this effect was observed in plants grown in soil fertilized with up to $1.02 \mathrm{~g} \mathrm{P}_{2} \mathrm{O}_{5} \mathrm{~kg}^{-1}$ whereas, in those inoculated with $D$. heterogama, the effect was observed in soils fertilized with up to $0.85 \mathrm{~g} \mathrm{P}_{2} \mathrm{O}_{5} \mathrm{~kg}^{-1}$ (Figure 2). In soils that received higher doses, the increase was lower in inoculated plants than in non-inoculated plants because, in relation to the increase of $\mathrm{P}$ doses, the increasing behavior of leaf area was linear for non-inoculated plants and exponential for those inoculated. In plants inoculated with $R$. clarus, the increment with maximum efficiency $(10 \%$ of the maximum increment) was observed in plants grown with $0.13 \mathrm{~g} \mathrm{P}_{2} \mathrm{O}_{5} \mathrm{~kg}^{-1}$, i.e. $91 \%$ lower than the recommended dose. In soils with $50 \%$ of the recommended $\mathrm{P}$ dose $\left(0.74 \quad \mathrm{~g}_{2} \mathrm{P}_{2} \mathrm{O}_{5} \mathrm{~kg}^{-1}\right)$, the increment in leaf area of plants inoculated with $R$. clarus was $6 \%$ higher than those non-inoculated. In soils fertilized with the highest $\mathrm{P}$ dose $\left(2.96 \mathrm{~g} \mathrm{P}_{2} \mathrm{O}_{5}\right.$ $\mathrm{kg}^{-1}$ ), the increment of leaf area of plants inoculated with this fungus was $23 \%$ lower than in noninoculated plants. The other inoculation treatments also showed the same behavior in the increase of leaf area, i.e. they were lower when compared with the control in high $\mathrm{P}_{2} \mathrm{O}_{5}$ doses.

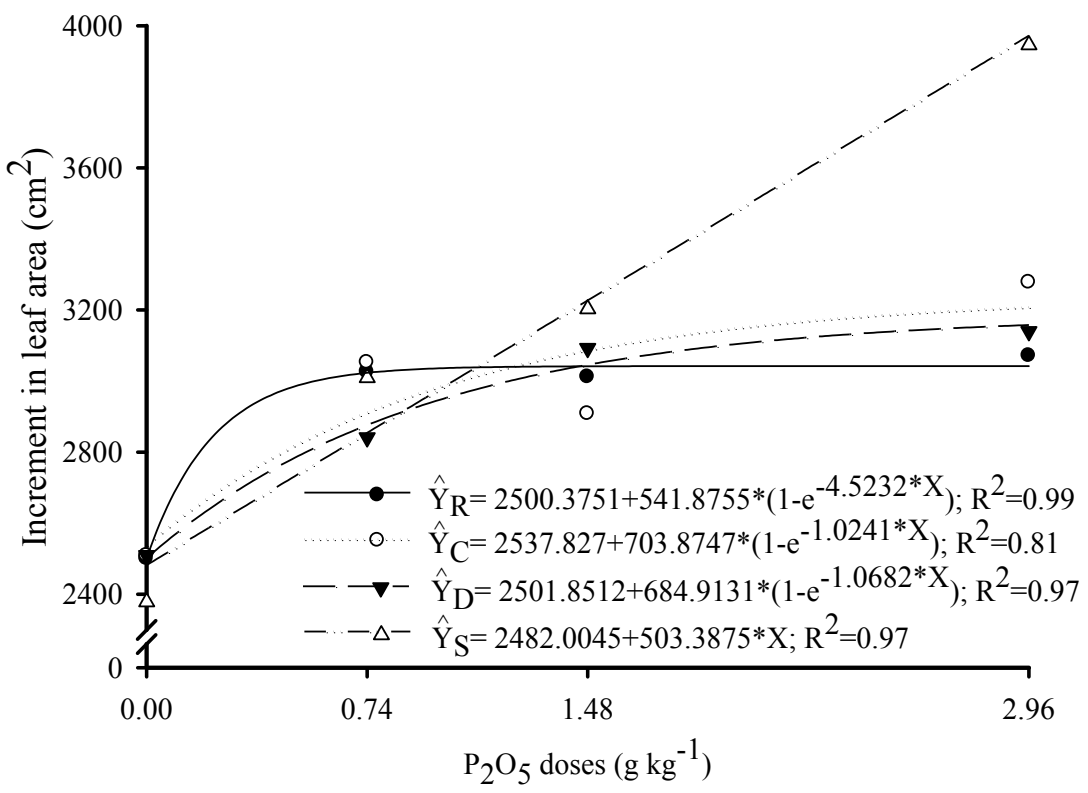

Figure 2. Increment in leaf area of coffee (Coffea arabica) inoculated with Rhizophagus clarus $\left(\mathrm{Y}_{\mathrm{R}}\right)$, Claroideoglomus etunicatum $\left(\mathrm{Y}_{\mathrm{C}}\right)$ and Dentiscutata heterogama $\left(\mathrm{Y}_{\mathrm{D}}\right)$, and non-inoculated $\left(\mathrm{Y}_{\mathrm{S}}\right)$ and grown in soil with increasing $\mathrm{P}_{2} \mathrm{O}_{5}$ doses. 
Root dry mass (RDM) presented a quadratic behavior for the four fungal treatments with increasing $\mathrm{P}$ doses, but the intensity of this effect was dependent on the inoculation condition (Figure 3 ). The highest RDM (21.7 g) was observed in plants inoculated with $D$. heterogama grown in soils fertilized with $1.56 \mathrm{~g} \mathrm{P}_{2} \mathrm{O}_{5} \mathrm{~kg}^{-1}$, followed by those non-inoculated in soil fertilized with $1.61 \mathrm{~g} \mathrm{P}_{2} \mathrm{O}_{5}$ $\mathrm{kg}^{-1}$, inoculated with $R$. clarus in soil fertilized with $1.28 \mathrm{~g} \mathrm{P}_{2} \mathrm{O}_{5} \mathrm{~kg}^{-1}$, and inoculated with C. etunicatum in soil fertilized with $1.98 \mathrm{~g} \mathrm{P}_{2} \mathrm{O}_{5} \mathrm{~kg}^{-1}$. The control presented a maximum RDM of $20.8 \mathrm{~g}$. The lowest RDM was observed in plants inoculated with $R$. clarus and C. etunicatum, in which the highest RDM for both treatments was $18.5 \mathrm{~g}$.

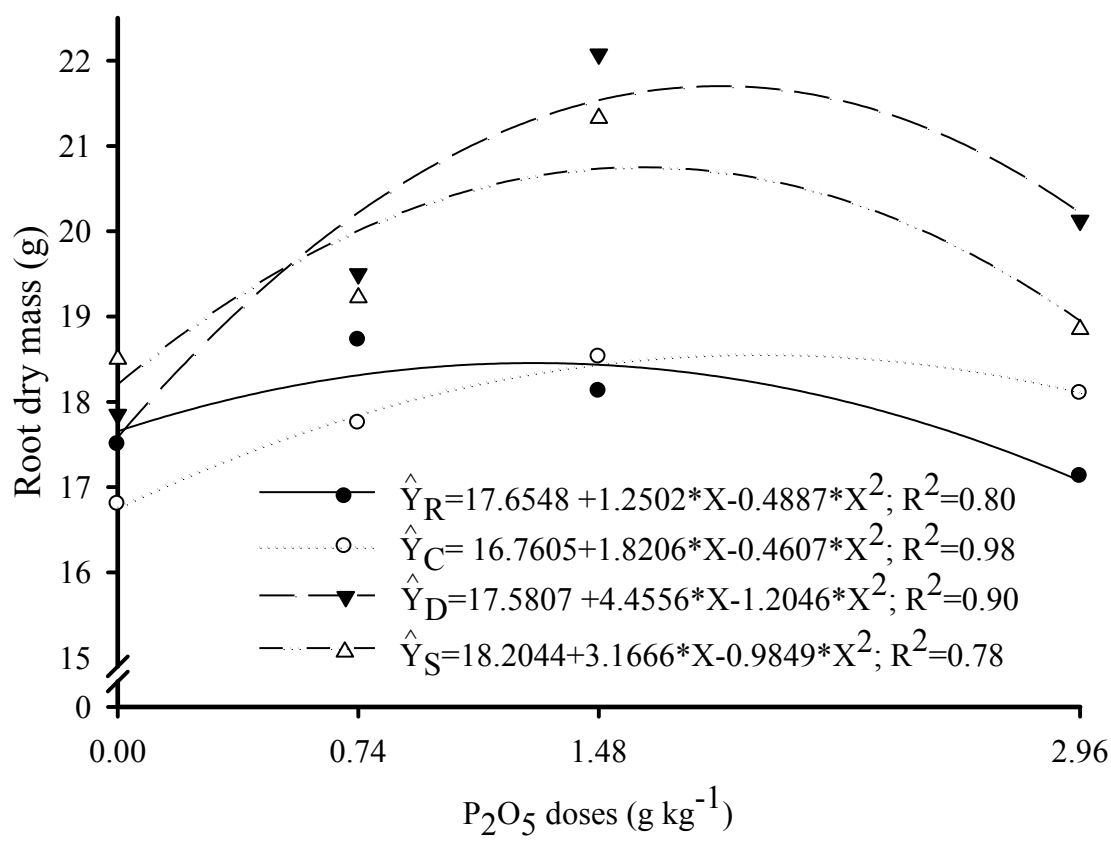

Figure 3. Root dry mass of coffee (Coffea arabica) inoculated with Rhizophagus clarus $\left(\mathrm{Y}_{\mathrm{R}}\right)$, Claroideoglomus etunicatum $\left(\mathrm{Y}_{\mathrm{C}}\right)$ and Dentiscutata heterogama $\left(\mathrm{Y}_{\mathrm{D}}\right)$, and non-inoculated $\left(\mathrm{Y}_{\mathrm{S}}\right)$ and grown in soil with increasing $\mathrm{P}_{2} \mathrm{O}_{5}$ doses.

The percentage of colonized root length and number of AMF spores were higher in inoculated plants when compared to those non-inoculated and decreased linearly as the $\mathrm{P}_{2} \mathrm{O}_{5}$ dose increased under all inoculation conditions (Figure 4). The percentage of colonized root length was 37 to $60 \%$ higher in plants grown in soil non-fertilized with $\mathrm{P}$ when compared to those that received the highest dose $\left(2.96 \mathrm{~g} \mathrm{P}_{2} \mathrm{O}_{5} \mathrm{~kg}^{-1}\right)$. However, the number of spores was 58 to $60 \%$ higher in non-fertilized soils when compared in those that received the highest $\mathrm{P}$ dose, depending on the inoculation condition.

In non-fertilized soil, the percentage of colonized root length was, in a descending order, higher seedlings inoculated with $R$. clarus (36\%), $C$. etunicatum $(35 \%)$, D. heterogama $(34 \%)$, and noninoculated $(30 \%)$, but with a reduction in colonization for the three fungi as $\mathrm{P}$ doses increased (Figure 4A). At the highest dose, the percentage of root length equaled for the fungi $R$. clarus and $C$. etunicatum, being $81 \%$ higher when compared to non-inoculated plants. The number of spores was similar in soils where plants inoculated with the three AMF were grown and also reduced linearly as $P$ doses increased (Figure 4B). In the soil without fertilization, the number of spores was 45.6 per gram of soil (average of the three AMF), which was $40 \%$ higher than the number of spores in the soil where non-inoculated plants were grown. 

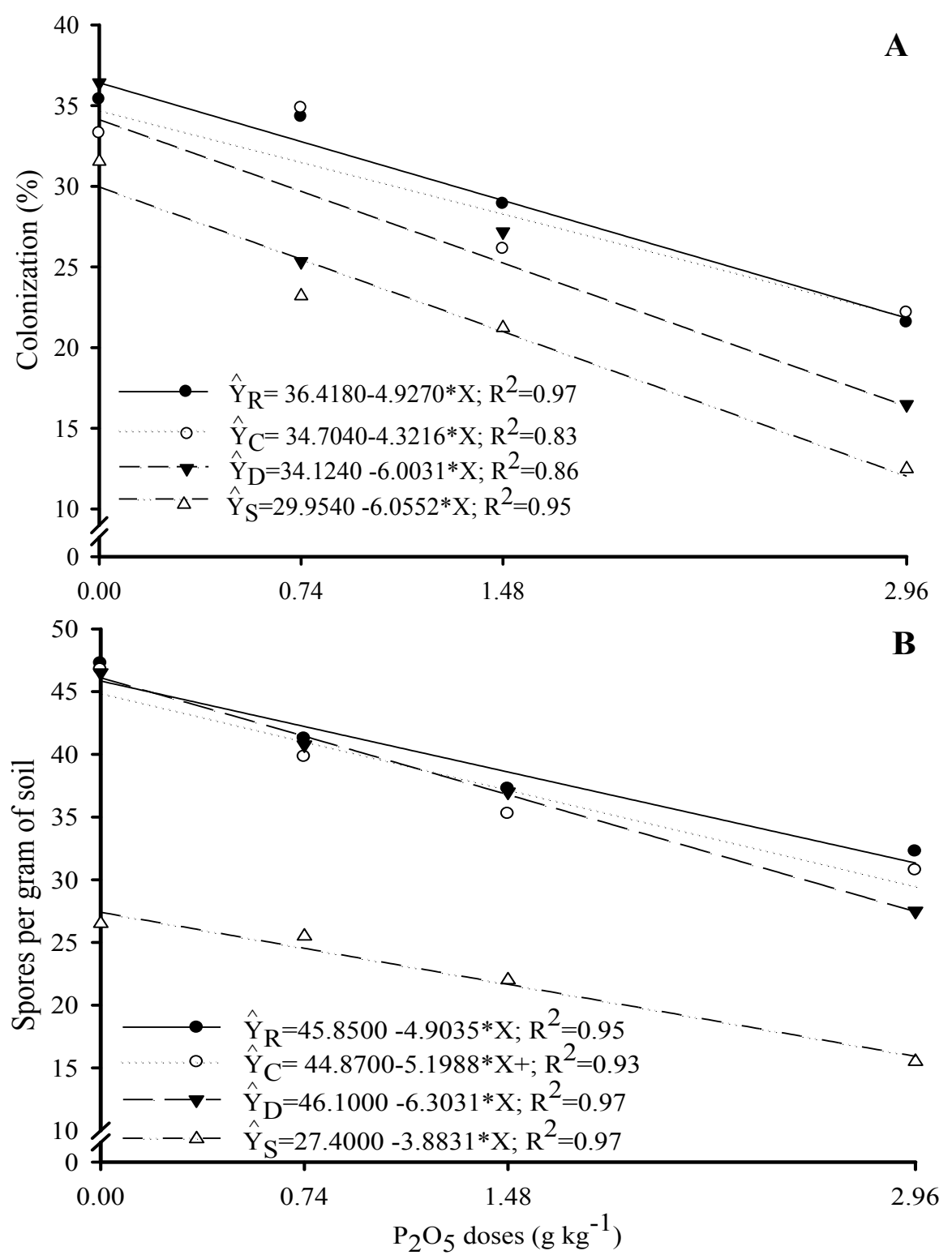

Figure 4. Percentage of root lengths colonized by fungi (colonization) (A) and number of spores per gram of soil (B) in rhizosphere of coffee (Coffea arabica) inoculated with Rhizophagus clarus $\left(\mathrm{Y}_{\mathrm{R}}\right)$, Claroideoglomus etunicatum $\left(\mathrm{Y}_{\mathrm{C}}\right)$ and Dentiscutata heterogama $\left(\mathrm{Y}_{\mathrm{D}}\right)$, and non-inoculated $\left(\mathrm{Y}_{\mathrm{S}}\right)$ and grown in soil with increasing $\mathrm{P}_{2} \mathrm{O}_{5}$ doses.

In the chemical analysis of soil and leaves, $\mathrm{P}$ presented a different behavior (Figure 5). Soils with inoculated plants presented higher $\mathrm{P}$ contents in relation to the control. However, in the highest $\mathrm{P}_{2} \mathrm{O}_{5}$ dose applied in this study, the control was close to the soil $\mathrm{P}$ content (Figure 5A). When comparing inoculated plants with the control within the recommended dose $\left(1.48 \mathrm{~g} \mathrm{P}_{2} \mathrm{O}_{5} \mathrm{~kg}^{-1}\right)$, the highest $\mathrm{P}$ values were observed in the soil: D. heterogama with $43 \%, C$. etunicatum with $41 \%$, and $R$. clarus with $40 \%$.

The contents of $\mathrm{P}$ in leaves of inoculated plants increased in a quadratic manner as $\mathrm{P}$ fertilization increased, whereas, in non-inoculated plants, this increase was linear (Figure 5B). In plants inoculated with $R$. clarus, $\mathrm{P}$ contents were always higher than those of non-inoculated plants, even with the highest $\mathrm{P}$ fertilization, with the highest content of $0.26 \mathrm{dag} \mathrm{kg}^{-1}$ at a dose of $2.15 \mathrm{~g} \mathrm{P}_{2} \mathrm{O}_{5} \mathrm{~kg}^{-1}$. The contents of $\mathrm{P}$ in plants grown in soils with higher $\mathrm{P}$ fertilizations were lower when compared to those observed in non-inoculated plants, with maximum contents of $0.22 \mathrm{dag} \mathrm{kg}^{-1}$ at doses of 1.78 and $1.96 \mathrm{~g}$ $\mathrm{P}_{2} \mathrm{O}_{5} \mathrm{~kg}^{-1}$ in plants inoculated with $D$. heterogama and $C$. etunicatum, respectively. 

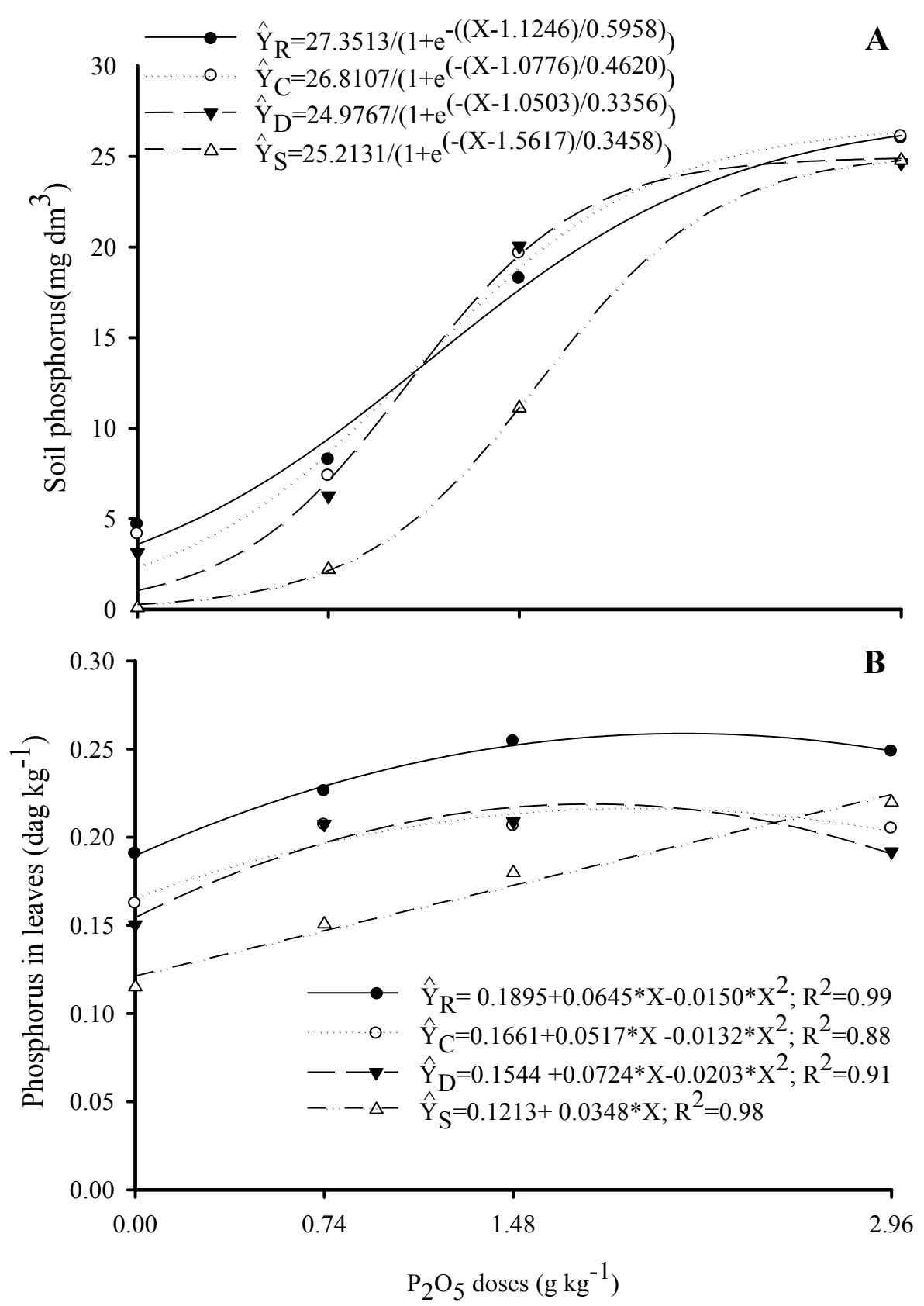

Figure 5. Phosphorus content in the soil (A) and in leaves (B) of coffee (Coffea arabica) inoculated with Rhizophagus clarus $\left(\mathrm{Y}_{\mathrm{R}}\right)$, Claroideoglomus etunicatum $\left(\mathrm{Y}_{\mathrm{C}}\right)$ and Dentiscutata heterogama $\left(\mathrm{Y}_{\mathrm{D}}\right)$, and non-inoculated $\left(\mathrm{Y}_{\mathrm{S}}\right)$ and grown in soil with increasing $\mathrm{P}_{2} \mathrm{O}_{5}$ doses.

In this study, a mycorrhizal dependence was observed for coffee plants with 150 DAP, cultivated in a soil without phosphate fertilizer application, although this dependence has decreased from the dose of $0.74 \mathrm{~g} \mathrm{~kg}^{-1}$. Thus, in more sustainable agricultural systems that are concerned with the risks of environmental contamination and depletion of $\mathrm{P}$ sources in nature, the use of coffee seedlings inoculated with AMF should be considered. This may still provide a lower production cost because it reduces the demand for phosphate fertilizers and may bring other benefits such as resistance to drought and soil pathogens.

The cultivation of plants under conditions of high $\mathrm{P}$ fertilization decreases the benefit of mycorrhizae (BALOTA; MACHINESKI; STENZEL, 2011a), root colonization (MUSTAFA et al., 2016; TAFFOUO et al., 2014), number of spores (SILVA et al., 2016), and AMF diversity (DE BEENHOUWER et al., 2015). Variables analyzed in experiments involving AMF and $\mathrm{P}$ doses have had a quadratic regression behavior as $\mathrm{P}$ increases because the effects of mycorrhiza are higher under lower $\mathrm{P}$ contents (BALOTA; MACHINESKI; STENZEL, 2011b).

High $\mathrm{P}$ contents usually inhibit the establishment of mycorrhiza according to the nutritional state of the plant and with the 
mechanisms of symbiotic self-regulation. Likewise, the number of spores is directly related to this characteristic (MOREIRA; SIQUEIRA, 2006). Under conditions of high doses of this nutrient, AMF may stop forming a mutualistic symbiosis and become parasitic, which may lead to a reduction of host growth. The mycorrhizal association is correlated with the carbohydrate cost of symbiosis, and when this cost exceeds AMF benefits, the association can reduce plant growth by up to $17 \%$ (RAMOS; MARTINS, 2010).

The inoculation of AMF on sterilized substrate promotes a higher plant growth since there is no competition with other microorganisms (SILVA JÚNIOR et al., 2012). In our experiment, the control presented AMF because the soil was not sterilized and mycorrhiza occurred naturally with the presence of native fungi. However, the inoculated treatments provided better results than the control treatments under conditions of low $\mathrm{P}$ content. The benefits of AMF inoculation for seedling production in non-sterile soil were also observed in coffee seedlings (FRANÇA et al., 2014), confirming the benefit of AMF introduced even in soils with native AMF.

Fungi $R$. clarus and $C$. etunicatum colonized more the coffee root system (Figure 4A) and provided a higher increase in height, leaf area (Figure 1 and 2), and number of fungal spores (Figure 4B). These AMF species have stood out in other studies of inoculations on seedlings aiming at coffee production (ALECRIM et al., 2016; FRANÇA et al., 2016).

The amount of nutrients available in the substrate influences the symbiosis, especially $\mathrm{P}$ (SILVA et al., 2009). The availability of $P$ in the soil is directly related to coffee growth and to the benefit of AMF. The type of arbuscular mycorrhizal inoculum also responds differently to the amount of $\mathrm{P}$ and may be more efficient in the absorption of this nutrient in low-fertility soils. Coffee plants associated with the fungus $R$. clarus is more efficient in $\mathrm{P}$ absorption in relation to the other treatments since it presents a higher $\mathrm{P}$ content in leaves and a lower $\mathrm{P}$ absorption in the soil (Figure 5).

\section{CONCLUSIONS}

The fungi Rhizophagus clarus and Claroideoglomus etunicatum promoted a higher growth of coffee plants in relation to non-inoculated plants even in non-sterilized soil with a reduction of the applied P, except for root dry matter. These fungi presented similar results in the colonization of the cultivar Catuaí Vermelho IAC 99, with a decrease in mycorrhizal colonization with an increase of $\mathrm{P}$ applied in the soil, but they were higher than in noninoculated plants. Arbuscular mycorrhiza provided a greater benefit in the growth of coffee plants cultivated in a non-sterilized soil with a low phosphate fertilization. Doses of $\mathrm{P}$ higher than $50 \%$ of the recommended dose ( $\left.\begin{array}{lllll}0.74 & \mathrm{~g}_{2} \mathrm{O}_{5} & \mathrm{~kg}^{-1}\end{array}\right)$ decreased the benefit of mycorrhiza.

\section{ACKNOWLEDGEMENTS}

To CNPq, to CAPES and to FAPEMIG, for their financial support to conduct this paper.

\section{REFERENCES}

ALECRIM, A. O. et al. Interference by Palisade Grass on Coffee Seedlings Inoculated with Arbuscular Mycorrhizal Fungi. Planta daninha, v. 34, n. 4, p. 681-689, 2016.

ANDRADE, E. M. et al. Fatores determinantes da qualidade das águas superficiais na bacia do Alto Acaraú. Ciência Rural, v. 37, n. 6, p. 1791-1797, 2007.

ANDRADE, S. A. L.; SILVEIRA, A. P. D.; MAZZAFERA, P. Arbuscular mycorrhiza alters metal uptake and the physiological response of Coffea arabica seedlings to increasing $\mathrm{Zn}$ and $\mathrm{Cu}$ concentrations in soil. The Science of the Total Environment, v. 408, n. 22, p. 5381-5391, 2010.

ANTUNES, W. C. et al. Allometric models for nondestructive leaf area estimation in coffee (Coffea arabica and Coffea canephora). Annals of Applied Biology, v. 153, n. 1, p. 33-40, 2008.

BALOTA, E. L.; MACHINESKI, O.; STENZEL, N. M. C. Mycorrhizal efficiency in acerola seedlings with different levels of phosphorus. Brazilian Archives of Biology and Technology, v. 54, n. 3, p. 457-464, 2011a.

BALOTA, E. L.; MACHINESKI, O.; STENZEL, N. M. C. Resposta da acerola à inoculação de fungos micorrízicos arbusculares em solo com diferentes níveis de fósforo. Bragantia, v. 70, n. 1, p. 166-175, $2011 \mathrm{~b}$.

BERNS, A. E. et al. Effect of gamma-sterilization and autoclaving on soil organic matter structure as studied by solid state NMR, UV and fluorescence spectroscopy. European Journal of Soil Science, v. 59, n. 3, p. 540-550, 2008.

DE BEENHOUWER, $M$. et al. Changing soil characteristics alter the arbuscular mycorrhizal fungi communities of Arabica coffee (Coffea arabica) in Ethiopia across a management intensity gradient. Soil Biology and Biochemistry, v. 91, s/n., p. 133- 
$139,2015$.

FRANÇA, A. C. et al. Mycorrhizal fungi increase coffee plants competitiveness against Bidens pilosa interference. Pesquisa Agropecuária Tropical, v. 46, n. 2, p. 132-139, 2016.

FRANÇA, A. C. et al. Crescimento de mudas de cafeeiro inoculadas com fungos micorrízicos arbusculares. Revista Brasileira de Ciências Agrárias, v. 9, n. 4, p. 506-511, 2014.

GERDEMANN, J. W.; NICHOLSON, T. H. Spores of mycorrhizal Endogone extracted from soil by wet sieving and decanting. Transactions of the British Mycological Society, v. 46, n. 2, p. 235-244, 1963.

GIOVANNETTI, M.; MOSSE, B. An evaluation of techniques for measuring vesicular arbuscular mycorrhizal infection in roots. New Phytologist, v. 84, n. 3, p. 489-500, 1980.

GUIMARÃES, P. T. G. et al. Cafeeiro. In: RIBEIRO, A. C.; GONTIJO, P. T.; ALVAREZ, V. H. (Eds.). Comissão de fertilidade do solo do estado de minas gerais. Recomendações para uso de corretivos e fertilizantes em Minas Gerais: 5 aproximação. Viçosa, MG: Comissão de Fertilidade do Solo do Estado de Minas Gerais, 1999. v. 1, cap. 18.4.6, p. 289-302.

GUIMARÃES, P. T. G.; REIS, T. H. P. Nutrição e adubação do cafeeiro. In: REIS P. R.; CUNHA R. L. da (Eds.). Café Arábica do plantio à colheita. 1. ed. Lavras: Unidade Regional EPAMIG Sul de Minas, 2010. v. 1, cap. 6, p. 343-414.

JEFFRIES, P.; BAREA, J. M. Arbuscular mycorrhiza - a key component of sustainable plantsoil ecosystems. In: HOCK, B. (Ed.). The mycota IX. Fungal Associations. 2. ed. Berlin: Springer Berlim Heidelberg, 2012. v. 1, cap. 4, p. 51-75.

LEMOS, V. T. et al. Ácido cítrico e fósforo no desenvolvimento e estado nutricional de mudas de café. Coffee Science, v. 10, n. 3, p. 298-308, 2015.

MALAVOLTA, E. Manual de nutrição mineral de plantas. 1. ed. São Paulo, SP: Agronômica Ceres, 2006. $638 \mathrm{p}$.

MOREIRA, F. M. S.; SIQUEIRA, J. O. Microbiologia e Bioquímica do Solo. 2. ed. Lavras, MG: UFLA, 2006. 729 p.

MUSTAFA, G. et al. Phosphorus supply, arbuscular mycorrhizal fungal species, and plant genotype impact on the protective efficacy of mycorrhizal inoculation against wheat powdery mildew.
Mycorrhiza, v. 26, n. 7, p. 685-697, 2016.

POSADA, R. H. et al. Effects of soil physical and chemical parameters, and farm management practices on arbuscular mycorrhizal fungi communities and diversities in coffee plantations in Colombia and Mexico. Agroforestry Systems, v. 92, n. 2, p. 555-574, 2018.

PHILLIPS, J. M.; HAYMAN, D. S. Improved procedures for clearing roots and staining parasitic and vesicular-arbuscular mycorrhizal for rapid assessment of infection. Transactions of the British Mycological Society, v. 55, n. 1, p. 158-161, 1970.

RAMOS, A. C.; MARTINS, M. A. Fisiologia de micorrizas arbusculares. In: SIQUEIRA, J. O. et al. (Eds.). Micorrizas: 30 anos de pesquisas no Brasil. Lavras, MG: UFLA, 2010. v. 1, cap. 5, p. 133-152.

SANTOS, E. A. et al. Occurrence of symbiotic fungi and rhizospheric phosphate solubilization in weeds. Acta Scientiarum Agronomy, v. 35, n. 1, p. 49-55, 2013.

SILVA, E. P. et al. Desenvolvimento e colonização micorrízica em mudas de embaúba adubadas com fosfato natural e material orgânico. Revista Ciência Agronômica, v. 47, n. 2, p. 256-263, 2016.

SILVA, T. F. B. et al. Influência da densidade de fungos micorrízicos arbusculares na produção de maracujazeiro-doce (Passiflora alata curtis). Revista Caatinga, v. 22, n. 4, p. 1-6, 2009.

SILVA JÚNIOR, J. M. T. et al. Efeito da esterilização do substrato sobre o crescimento de mudas de meloeiro em presença de fungos micorrízicos arbusculares e compostos orgânico. Revista Caatinga, v. 25, n. 1, p. 98-103, 2012.

SMITH, S. E. et al. Plant Performance in Stressful Environments: Interpreting New and Established Knowledge of the Roles of Arbuscular Mycorrhizas. Plant and Soil, v. 326, n. 1, p. 3-20, 2010.

TAFFOUO, V. D. et al. Influence of phosphorus application and arbuscular mycorrhizal inoculation on growth, foliar nitrogen mobilization, and phosphorus partitioning in cowpea plants. Mycorrhiza, v. 24, n. 5, p. 361-368, 2014 